\title{
EMIGRACJA - KULTURA - WOLNOŚĆ. O VINKU NIKOLICIU I SPEŁNIONYM ŚNIE O NIEPODLEGŁOŚCI
}

\author{
SZYMON PRZEKLASA
}

\begin{abstract}
Emigration - culture - freedom. Vinko Nikolic and his dream about the independence
We have the same enemy and the same motherland - the sentence by Vinko Nikolic is the essential one to describe his life, creativeness and a tragedy of the entity. This poet and emigre activist is well-known person in Republic of Croatia due to the loyalty to native culture and literature but also because being a controversial figure linked with the ultranationalist organization of Croatian Revolutionary Movement - Ustaša (which used to rule in Independent State of Croatia during World War II). The aim of the article is to show how Nikolić had become one of the most important Croat abroad during the existence of Socialist Federal Republic of Yugoslavia, how his connotations with Nazis really looked and how he changed views on the independence during being out of Croatia for almost 50 years.
\end{abstract}

STRESZCZENIE. Mamy wspólnego wroga, mamy wspólną ojczyznę - to zdanie autorstwa Vinka Nikolicia doskonale opisuje jego biografię, twórczość i tragedię życiową. Ten poeta i działacz emigracyjny jest dobrze znany w Chorwacji ze względu na jego przynależność do chorwackiej kultury i literatury, a także z powodu kontrowersyjnych związków z ultranacjonalistycznym ruchem ustaszowskim, który rządził Niezależnym Państwem Chorwackim (1940-1945). Celem artykułu jest ukazanie w jaki sposób V. Nikolić stał się jednym z najważniejszych chorwackich działaczy emigracyjnych w czasach istnienia socjalistycznej Jugosławii i jak zmieniły się jego zapatrywania na kwestię niezależności Chorwacji podczas blisko pięćdziesięcioletniego pobytu na emigracji.

SAŽETAK. Emigracija - kultura - sloboda. Vinko Nikolić i njegov san o nezavisnosti Isti nam je neprijatelj, ista nam je domovina - ova je Nikolićeva rečenica osnova za opisivanje njegova života, stvaralaštva te tragedije jedne osobe. Ovaj je pjesnik i emigrantski aktivist poznat u Hrvatskoj zbog odanosti hrvatskoj kulturi te književnosti, ali i zbog brojnih kontroverzi veza s ultranacionalističkim pokretom Ustaša (Hrvatske revolucionarne organizacije) koji je bio u vlastima Nezavisnoj Državi Hrvatske tijekom Drugog svjetskog rata. Cilj je ovog članka pokazati kako je Nikolić postao jedan od najvažnijih hrvatskih emigrantskih djelatnika u inozemstvu za vrijeme postajanja socjalističke Jugoslavije te koliko je promijenio svoje mišljenje o neovisnosti tijekom boravka izvan Hrvatske koji je trajao skoro 50 godina.

Author: Szymon Przeklasa, Uniwersytet Jagielloński, Wydział Filologiczny, Instytut Filologii Słowiańskiej, ul. Romana Ingardena 3, 30-060 Kraków, Polska. e-mail: szymon.przeklasa@doctoral.uj.edu.pl, ORCID iD: https://orcid.org/0000-0002-2309-8261

Keywords: Vinko Nikolić, Croatia, emigration, independence, culture, literature

Słowa kluczowe: Vinko Nikolić, Chorwacja, emigracja, niepodległość, kultura, literatura

Ključne riječi: Vinko Nikolić, Hrvatska, emigracija, nezavisnost, kultura, književnost

Balcanica Posnaniensia. Acta et studia, XXVI, Poznań 2019, Wydawnictwo Instytutu Historii UAM, pp. 213229, ISBN 978-83-66355-32-3, ISSN 0239-4278. Polish text with summaries in English, Polish and Croatian.

doi.org/10.14746/bp.2019.26.12 
Isti nam je neprijatelj, ista nam je domovina. ${ }^{1}$

Vinko Nikolić

Republika Chorwacji to państwo, które na mapie Europy funkcjonuje od zaledwie 28 lat. Proklamacja niepodległości z 1991 roku, przyczyniająca się częściowo ${ }^{2}$ do rozpadu tak zwanej „drugiej Jugosławii”’, trwającej w nienaruszonym kształcie od początku 1945 roku, była spełnieniem marzeń ogromniej części chorwackiego społeczeństwa, jak i samego Vinka Nikolicia - poety, pisarza emigracyjnego, wieloletniego redaktora naczelnego emigracyjnego czasopisma „Hrvatska revija”, ale również postaci związanej z chorwackim ruchem faszystowskim w trakcie II wojny światowej. To właśnie V. Nikolić, będący przez długi czas na emigracji z powodów politycznych, na łamach periodyku nawoływał do walki o niepodległość nacji i pielęgnował pamięć o jej kulturze i tradycji. Celem niniejszej pracy jest przyjrzenie się sylwetce Vinka Nikolicia, jego poglądom politycznym (w tym: działaniom podejmowanym w trakcie i po II wojnie światowej), wybranym aspektom jego twórczości oraz rzucenie światła na istotę wolności ${ }^{4}$ jako waloru, którego konieczność istnienia często podkreślał w swych tekstach.

\section{CEL UŚWIĘCA ŚRODKI - IDEOLOGIA USTASZOWSKA JAKO DROGA DO NIEPODLEGŁOŚCI}

Vinko Nikolić w oczach rodaków był nie tylko pisarzem, poetą i działaczem kulturalnym, ale także jedną z najważniejszych postaci chorwackiego exodusu, do którego dołączył wraz z zakończeniem drugiej wojny światowej ${ }^{5}$. Z drugiej zaś strony - niewiele w obecnej Chorwacji mówi się o przynależności samego autora do szeregów działaczy Niezależnego Państwa Chorwackiego $(\mathrm{NDH})^{6}$, które funkcjonowało pod

${ }^{1}$ Mamy wspólnego wroga, mamy wspólną ojczyznę. Wszystkie thumaczenia, jeśli nie zaznaczono tego inaczej - S.P.

2 Jest to wyłącznie jeden z powodów rozpadu Jugosławii, obok (między innymi) polityki prowadzonej Slobodana Miloševicia oraz wzrostu serbskich tendencji nacjonalistycznych z nią związanych.

3 Jako „Drugą Jugosławię”” zwyczajowo określa się komunistyczną Republikę Jugosławii w celu jej odróżnienia od „pierwszej”, funkcjonującej jako Królestwo Serbów, Chorwatów i Słoweńców (19181929) oraz Królestwo Jugosławii (1929-1941).

${ }^{4}$ Warto odnotować, iż wolność u Nikolicia odnosi się do więcej niż jednego pojęcia i nie powinna być odbierana jednoznacznie; jest ona ściśle związana z kilkoma płaszczyznami: kulturalną (twórczą), polityczną (niepodległościową) i mentalną (dotyczącą samoświadomości Chorwatów o wolności własnego narodu).

${ }^{5}$ V. Nikolić, Predgovor, w: V. Grubišić, Hrvatska književnost u egzilu, Knjižnica Hrvatske revije, Barcelona - München 1991., s. 160.

${ }^{6}$ Niezależne Państwo Chorwackie (chorw. Nezavisna Država Hrvatska) - państwo marionetkowe pod protektoratem III Rzeszy Niemieckiej oraz faszystowskich Włoch. Wraz z rozpadem sojuszu państw Osi, w 1945 roku oddziały partyzanckie pod dowództwem Josipa Broza Tity - późniejszego przywódcy komunistycznej Jugosławii - zakończyły istnienie NDH. 
rządami faszystowskiego ruchu ustaszy ${ }^{7}$ na czele z Ante Paveliciem - osobą odpowiedzialną za ludobójstwo i zbrodnie przeciwko innym narodom (głównie Serbom, Żydom i Romom) ${ }^{8}$ - to właśnie jego poplecznikiem (według C. Hegesa adiutantem ${ }^{9}$ ) w czasach młodości był Nikolić.

Fascynacja ruchem ustaszowskim była widoczna w jego pierwszych felietonach i wierszach, o czym wspomina między innymi Fikreta Jelić-Butić w monografii: Ustaše i Nezavisna Država Hrvatska 1941.-1945. ${ }^{10}$. Inteligencja i warstwa wykształcona miały mieć szczególne znaczenie w kształtowaniu umysłów chorwackiej młodzieży w myśl wizji ustaszowskiej, opartej na kulcie Ante Pavelicia, o czym przekonywał młody Vinko Nikolić w jednym z tekstów ${ }^{11}$ na łamach dziennika propagandowego Ustaša z 1941 roku: Naša nova inteligencija mora buduće hrvatske naraštaje odgajati po ustaškim načelima i u prvom redu mora uzgojiti među čitavom hrvatskom omladinom još u najranijoj dobi neograničenu i požrtvovnu odanost prema vođi. ${ }^{12}$. Słowa 29-letniego wówczas Nikolicia bezsprzecznie sytuują go pośród entuzjastów ruchu ustaszowskiego, a jego działalność autorska - według Jelić-Butić była symptomatyczna dla haseł, z jakimi identyfikowali się działacze NDH; teksty Vinka Nikolicia opierały się głównie na wizji ,artystycznego kształtowania majestatycznej chorwackiej teraźniejszości" "13 którą promował wśród tamtejszych pisarzy, co miało się przełożyć na „stworzenie nowego człowieka” o „nacjonalistycznej duszy”, „ustaszowskim sercu”, „myśli przywódcy”, czy „,ustaszowskiej wierze”. Utrzymywał on podobną retorykę w artykule: Ustaštvo je nosilac novog poredka ${ }^{14}$ (na łamach tego samego czasopisma) z 1942 roku pisząc, że ustasza nie może być wyłącznie: „bastionem swojego państwa, jego strażnikiem i obrońcą, odważnym żołnierzem i wojownikiem”, a wizja ideologii nie odwołuje się jedynie do „pojęcia heroizmu” ale do rewolucji, która ma odbyć się na płaszczyźnie duszy, która wymaga skonstruowania nowego człowieka, co poświadczają słowa o konieczności „zbudowania usta-

${ }^{7}$ Ustasze (chorw. Ustaše) - potoczne określenie chorwackich nacjonalistów z organizacji Ustaša. Hrvatski oslobodilački pokret. Organizację ustaszy założył 1929 we Włoszech A. Pavelić. Celem ustaszy była secesja Chorwacji ze zdominowanej przez Serbów Jugosławii. Ustasze ponoszą odpowiedzialność za masowe mordy Serbów, Żydów i Cyganów zamieszkałych w państwie chorwackim.

${ }^{8}$ Patrz przypis nr 6.

${ }^{9}$ C. Heges, Fascists Reborn as Croatia's Founding Fathers, "New York Times", 12.04.1997; https://www.nytimes.com/1997/04/12/world/fascists-reborn-as-croatia-s-founding-fathers.html [dostęp: 18 kwietnia 2018].

${ }^{10}$ Wśród nich m.in. Ustaša oraz Ustaška mladež; F. Jelić-Butić, Ustaše i Nezavisna Država Hrvatska 1941-1945., Zagreb 1977.

${ }^{11}$ Fikreta Jelić-Butić nie zawarła w swej publikacji tytułu przytaczanego tekstu.

${ }^{12}$ Nasza nowa inteligencja musi przyszłe chorwackie pokolenia wychowywać zgodnie z ustaszowskimi zasadami, a przede wszystkim winna pielęgnować wśród catej chorwackiej młodzieży, już od najmłodszych lat, nieograniczona i ofiarna lojalność wobec przywódcy [Ante Pavelicia-S.P.]; ibidem, s. 201.

13 Ibidem, s. 202.

14 Tłum.: Myśl ustaszowska jest nośnikiem nowego porzadku; R. Yeomans, Army Educators and the Making of a "Total Man" in Late Fascist Croatia, Rory Yeomans w: The "New Man" in Radical Right Ideology and Practice, 1919-45, M. Feldman, J. Dagnino, P. Stocker, London 2018, s. 110. 
szy/nowego człowieka w nas samych."15. Wizje, jakie zarysował V. Nikolić w swych tekstach, miay doprowadzić do jak najszybszego stworzenia „nowej, ustaszowskiej literatury"16. Chorwacki pisarz widział w tych założeniach drogę do niepodległości narodu, pisząc we wrześniu 1941 roku w dzienniku Ustaška mladež ${ }^{17}$ : „Naszą religią jest Niezależne Państwo Chorwackie” czy też „Wszyscy jesteśmy wyznawcami tej naszej boskiej wiary."18

Koniec drugiej wojny doprowadził do upadku satelickiego państwa nazistowskich Niemiec, a późniejszy redaktor naczelny „Chorwackiej Rewii”, uzyskując status jeńca wojennego, trafił na dwa lata do brytyjskiego obozu pracy we Włoszech (Grumo Appula oraz Grottaglie) ${ }^{19}$, by następnie uciec $\mathrm{z}$ pociągu transportującego chorwackie wojsko i cywili do kolejnego miejsca przetrzymywania, czym uniknął deportacji do Jugosławii, a tym samym rozliczenia z będącymi przy władzy komunistami. Wydarzenia te oraz tragedia, jaka rozegrała się w Bleiburgu w 1945 roku ${ }^{20}$ (którą przeżył i o której V. Nikolić wspominał w swej późniejszej twórczości niejednokrotnie), z pewnością wywołały traumę w jego psychice (co pośrednio zmusiło go do rozłąki z półwyspem Bałkańskim), nie spowodowały one jednak, że późniejszy długoletni redaktor naczelny „Chorwackiej Rewii” odszedł natychmiast od swych poglądów i kultu jednostki w osobie Pavelicia. W 1949 roku, to jest: w dwa lata po ucieczce z Europy, V. Nikolić wydał

\footnotetext{
${ }^{15}$ Ibidem.

16 Przytoczone słowa pochodzą z publikacji Nacionalni zadatci književnosti, wydanej w Zagrzebiu w 1944 roku. Jest to zbiór artykułów, które Vinko Nikolić miał publikować na łamach gazet i czasopism ustaszowskich w latach 1942-1944. Godnym odnotowania jest również fakt, że podobne poglądy wyraził Marko Čović, ówczesny redaktor czasopisma „Chorwacka revija” (którą w późniejszym czasie reaktywował Nikolić na potrzeby szerzenia chorwackiej kultury na emigracji). M. Čović w 1942 roku pisał o powinności pisarzy w państwie ustaszowskim, ich roli pierwszych tlumaczy wielkich idei i sit, które skrywa w sobie ruch ustaszowski oraz o pierwszych budowniczych nowego myślenia, które jest nacionalistyczne, chorwackie, zdrowe i zbawienne; Ustaše i Nezavisna Država..., op. cit., s. 202.

17 Tłum.: Ustaszowska młodzież.

${ }^{18}$ R. Yeomans, Cults of Death and Fantasies of Annihilation: the Croatian Ustasha Movement in Power, 1941-1945 w: "Central Europe" 2005, t. 3, nr 2, s. 238; https://www.academia.edu/8131714/Cults of_Death_and_Fantasies_of_Annihilation_The_Croatian_Ustasha_Movement_in_Power_1941_45 [dostęp: 17 stycznia 2019].

19 Tko je tko u NDH - Hrvatska 1941.-1945., red. Z. Dizdar, M. Grčić, S. Ravlić, D. Stuparić, Zagreb 1997., s. 295.

${ }^{20} \mathrm{~W} 1945$ roku, w Bleiburgu, miejscowości na ówczesnym pograniczu jugosłowiańsko-austriackim, miała miejsce zbrodnia dokonana przez wojska jugosłowiańskie, w której śmierć poniosły tysiące osób. Według Slavka i Iva Goldsteinów, chorwackich historyków powołujących się na słowa Vladimira Žerjavića, rzeczywista liczba ofiar mogła sięgnąc 50 tysięcy osób (Chorwatów, Bośniaków i Boszniaków - to jest: bośniackich muzułmanów). Trudno jest określić rzeczywistą liczbę ze względu na zawyżone kalkulacje ze strony chorwackiej emigracji, podającej liczby sięgające nawet setek tysięcy; I. Goldstein, S. Goldstein, Jasenovac i Bleiburg nisu isto, Zagreb 2011, s. 313-317. Wśród współwinnych zbrodni wymienia się np. żołnierzy brytyjskich, którzy oddali część chorwackich jeńców wojennych armii jugosłowiańskiej; A. Jakir, P. Vulić, Recepcija Bleiburga u hrvatskoj javnosti kao tema povijesnog istraživanja, „Zbornik radova Filozofskog fakulteta u Splitu” 2016, nr 6-7, s. 195-198; https://hrcak.srce.hr/index. php?show=clanak\&id_clanak_jezik=227856 [dostęp: 17 kwietnia 2018].
} 
(własnym nakładem) tomik wierszy Molitva za moju Hrvatsku ${ }^{21}$ (znany wcześniej jedynie jako rękopis - prawdopodobnie niekompletny) ${ }^{22}$, będący zbiorem poematów wyrażających tęsknotę za Chorwacją (w istocie za Niezależnym Państwem Chorwackim), ale także sławiących naczelnika państwa - Ante Pavelicia. Wśród utworów znajduje się między innymi: Pożegnanie z Nim (Oproštaj s Njim) ${ }^{23}$ z 1945 roku, gdzie tytułowy „On”, to nikt inny, jak naczelnik państwa NDH, o czym świadczą wersy:

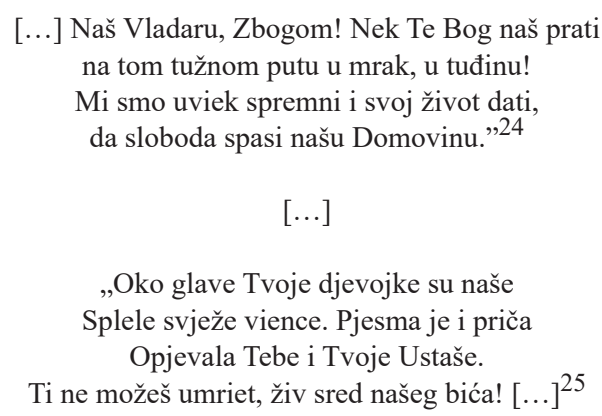

Jak widzimy, Vinko Nikolić w pierwszych latach emigracji nadal przejawiał poglądy nacjonalistyczne, osadzone w ideologii ustaszowskiej, a sama postać Ante Pavelicia wciąż była dla niego ważna. Pomimo teoretycznie wielkiej idei, jaką miało być uzyskanie niepodległości przez Chorwację, dostrzegalny jest silny związek z poglądami o zabarwieniu faszystowskim. Wizja chorwackiego państwa w oczach Vinko Nikolicia z biegiem czasu ulegała zmianie, co postaram się udowodnić w dalszej części tekstu.

\section{ŻYCIE DLA CHORWACJI POZA JEJ GRANICAMI}

Vinko Nikolić, zmuszony do ucieczki z Rzymu ${ }^{26}$, początkowo udał się do Marsylii, skąd - w 1947 roku - przeniósł się do Buenos Aires. Na emigracji przebywał przez niemal całą resztę swojego życia; w czasie wygnania mieszkał we Włoszech, Argentynie, Francji, Niemczech czy wreszcie Hiszpanii, by po prawie 45 latach tułaczki, jesienią 1990 roku, powrócić do Chorwacji. V. Nikolić niestrudzenie wierzył w realiza-

21 Tłum.: Modlitwa za moją Chorwację; V. Nikolić, Molitva za moju Hrvatsku, Buenos Aires 1949.

22 Vladimir Kovačić, Vinko Nikolić - Izabrana djela..., op. cit., s. 229.

23 V. Nikolić, Molitva za moju Hrvatsku..., op. cit., s. 9.

${ }^{24}$ Nasz Władco, Żegnaj! Niech Cię Bóg nasz strzeże, na tej smutnej drodze w mrok, w obczyźnie! My jesteśmy zawsze gotowi oddać swoje życie, by wolność zbawiła nasza Ojczyznę.; ibidem.

${ }^{25}$ Wokół głowy Twojej, dziewczęta nasze oplataja świeże wieńce, wiersz i opowieść opiewają Ciebie i Twoich Ustaszy. Ty nie możesz umrzeć, żyw pośród naszego istnienia!; ibidem.

${ }^{26}$ We włoskiej stolicy rozpoczął podyplomowe studia slawistyczne i pracę nad doktoratem związanym z nowoczesną chorwacką poezją. Niemniej, ze względu na groźbę deportacji do Jugosławii, zmuszony był opuścić Włochy; Tko je tko u NDH..., s. 295. 
cję idei niepodległościowej, jaką żył na emigracji przez kilka dekad ${ }^{27}$. Pewne jest jednak, że lata spędzone poza granicami ojczyzny zmusiły chorwackiego literata do walki, w której jedynym orężem pozostawało pióro, a bywa ono niejednokrotnie silniejsze od miecza.

Znakomitą część twórczości Vinko Nikolicia stanowi poezja ${ }^{28}$ - szczególnie patriotyczna ${ }^{29}$, o czym świadczą słowa: Nikolić je nacionalni pjesnik, i kao pjesnik nacionalni borac. Nitko u hrvatskoj književnosti nije tako [...] bez ikakva ostatka povezao pjesništvo $i$ domoljublje. ${ }^{30}$. Nie była to jednak jedyna dziedzina sztuki, którą przejawiał zainteresowanie. W początkowych latach swojego pobytu w Argentynie rozpoczął on działalność publicystyczną wraz z wydaniem pierwszego numeru dwutygodnika „Hrvatska” poświęconego tematom polityczno-kulturalnym. Wagę tego wydarzenia - zdaniem Dubravka Jelčicia - poświadczyła aprobata ze strony chorwackiej diaspory w Ameryce Południowej - powstanie czasopisma na nowo miało rozbudzić nadzieję wśród tamtejszych emigrantów. Wiara w niepodległą ojczyznę nie opierała się wyłącznie na kilku stronach periodyku, ale przede wszystkim na symbolu twórczości poświęconej ojczyźnie ${ }^{31}$.

Pomimo sukcesu przedsięwzięcia związanego z pierwszym wydawnictwem, prawdziwym opus vitae Nikolicia było, wspólnie z Antunem Bonifačiciem, reaktywowanie „Chorwackiej Rewii” - zagrzebskiego miesięcznika literackiego, który w latach 1928 - 1945 stanowił źródło różnorodnych tekstów (na łamach czasopisma publikowano między innymi prozę, poezję, eseistykę, czy też krytykę, a w czasach $\mathrm{NDH}$ teksty propagandowe ${ }^{32}$ ). Wydarzenie to - według Jelčicia - stanowi kamień milowy dla chorwackiej literatury:

Od toga dana, pa sve do kraja 1990., dakle punih četrdeset godina, Nikolićeva „Hrvatska revija” [...] izlazila je redovito i bez kašnjenja ili zaostatka, tromjesečno, četiri puta godišnje u omašnim svescima, kao smotra za književnost, znanost, kulturna i politička pitanja Hrvata ne samo u dijaspori, nego i u domovini, iz broja u broj sve bolja i sve opsežnija, dostigavši ubrzo, za samo godinu ili dvije, zavidno visoku razinu kako tiskanih priloga tako i uredničke koncepcije. ${ }^{33}$

${ }^{27}$ Vladimir Kovačić, Vinko Nikolić - Izabrana djela, Stoljeća hrvatske književnosti, red. V. Pavletić, przyg. D. Jelčić, Zagreb 1997, t. 21, s. 207.

${ }^{28}$ V. Nikolić jest autorem licznych zbiorów, wśród nich znajdują się m.in. Svijetli putovi (1939), Oskvrnuto proljeće (1947), czy Gorak je zemje kruv (1977).

${ }^{29}$ Przykładem niech będzie utwór Grob u srcu (pol. Grób w sercu) ze zbioru: Duga nad porušenim mostovima (pol. Tęcza nad zniszczonymi mostami) z 1964 roku, gdzie V. Nikolić pisze: [...] Domovino moja, srećo izgubljena, kad izgubih tebe, sve sam izgubio: Ti si moja mati, ljubovca i žena! (pol. Ojczyzno moja, szczęście utracone, gdy stracitem Ciebie, wszystko stracitem: Tyś moją matka, kochanka i żona!); Vladimir Kovačić, Vinko Nikolić - Izabrana djela..., op. cit. s. 296.

${ }^{30}$ Nikolić jest narodowym poeta, a jako poeta - narodowym wojownikiem. Nikt w chorwackiej literaturze tak [...] bez reszty nie powiazat poezji i patriotyzmu; ibidem, s. 210.

${ }^{31}$ Vladimir Kovačić, Vinko Nikolić - Izabrana djela..., op. cit., s. 216.

32 Vide: przypis nr 16.

33 Od tego dnia, aż do końca 1990 roku, czyli przez petne 40 lat, ,,Chorwacka Rewia” Nikolicia [...] wychodziła regularnie i bez opóźnienia czy zaległości - co trzy miesiące, cztery razy w ciagu roku, w okazatych tomach, jako przeglad literatury, nauki, kwestii kulturalnych i politycznych Chorwatów nie tylko 
„Chorwacka Rewia“, której celem było przede wszystkim krzewienie chorwackiej kultury na emigracji, miała także swoje symboliczne znaczenie - również na terenie Jugosławii, gdzie periodyk wpisany został na listę dzieł zakazanych, a jego czytanie równoznaczne było z popełnieniem przestępstwa. Przekaz informacji (między innymi związanych $\mathrm{z}$ wydarzeniami $\mathrm{w}$ samej Chorwacji), a także pluralizm tematyczny stanowić mogły bezpośrednie zagrożenie dla utrzymywania obowiązującej w Socjalistycznej Federacyjnej Republice Jugosławii monochromatycznej wizji wspólnego państwa wielu nacji ${ }^{34}$. Na szczególną uwagę zasługuje również fakt, że na czele magazynu stał V. Nikolić, który w czasach drugiej wojny światowej opowiadał się po stronie Niezależnego Państwa Chorwackiego, nie zaś oddziałów partyzanckich pod dowództwem Josipa Broza Tity. Pomimo wydania 160 numerów czasopisma, dialog z komunistycznym rządem był nieosiągalny, rzecz oczywista. Wysiłek włożony w publikowanie doprowadził jednak do czegoś znacznie ważniejszego z punktu widzenia samego autora - rozbudzenia wśród wielu Chorwatów wiary w to, że marzenie o życiu w niepodległym państwie może się ziścicićn.

V. Nikolić odczuwał jednak, że „Chorwacka Rewia” nie jest wystarczającym orężem do walki o wolność narodu, dlatego - w 1957 roku - rozpoczął pracę nad kolejnym, ściśle związanym ze swoim dziełem, projektem kulturalno-wydawniczym. „Knjižnica Hrvatske revije” - bo o niej właśnie mowa - była wydawnictwem opartym na cyklicznym przedstawianiu dorobku znanych chorwackich emigrantów (zarówno literatów, poetów, jak i reprezentantów innych dziedzin sztuki) ${ }^{36}$. Skala rozmachu, z jaką działał autor oraz rzesza jego współpracowników (wśród nich byli między innymi: rzeźbiarz Ivan Meštrović, oraz literaci: Bogdan Radica czy Dušan Žanko) ${ }^{37}$, świadczą jedynie o silnym dążeniu Nikolicia do walki o własny naród poprzez pielęgnowanie jego kultury. Nadzieje na uzyskanie niepodległości Chorwacji stawały się coraz bardziej realne wraz z każdą kolejną publikacją inteligencji emigracyjnej, zwłaszcza gdy zbiegły się z wydarzeniami natury politycznej w Zagrzebiu, gdzie w 1971 roku doszło do masowych protestów ze strony studentów i intelektualistów, którzy wyrazili swoje niezadowolenie z sytuacji chorwackiego narodu żyjącego w ramach Socjalistycznej Federacyjnej Republiki Jugosławii - ruch ten znany jest dziś jako „Chorwacka Wiosna” 38 .

$w$ diasporze, ale $i$ w ojczyźnie, z numeru na numer coraz lepsza i obszerniejsza, szybko osiagając w ciagu roku, czy dwóch, godny pozazdroszczenia poziom - zarówno drukowanych materiałów, jak i koncepcji redakcyjnej.; D. Jelčić, Predgovor w: Vladimir Kovačić, Vinko Nikolić - Izabrana djela..., op. cit., s. 216.

${ }^{34}$ Ibidem, s. 218.

${ }^{35}$ Vladimir Kovačić, Vinko Nikolić - Izabrana djela ..., op. cit., s. 218-219.

${ }^{36}$ Ibidem, s. 221-222.

${ }^{37}$ V. Nikolić skupił wokół „Chorwackiej Rewii” około 600 współpracowników i osób działających na rzecz czasopisma. Poza tekstami od autorów emigracyjnych, artykuły były także regularnie przesyłane przez artystów z ojczyzny, a ich dzieła ukazywały się na łamach periodyku pod pseudonimem lub bez podpisu; przypis $\mathrm{nr} 33$.

${ }^{38}$ Protesty przeciwko rzekomej dyskryminacji ekonomicznej i społecznej przyniosły skutek w postaci umieszczenia w jugosłowiańskiej konstytucji z 1974 roku zapisów zapewniających republikom większą 


\section{IDEA WALKI SŁOWEM ${ }^{39}$}

Większość tekstów Nikolicia na łamach „Chorwackiej Rewii” oraz siostrzanych publikacji stanowią artykuły wprowadzające, będące pewnego rodzaju przedmową do zawartości całego wydania - jako redaktor naczelny, V. Nikolić próbował trafić do czytelników słowem opartym na motywacji i potrzebie pielęgnowania chorwackiej kultury, gdyż to właśnie z nią powinien identyfikować się naród walczący o wolność własnego kraju; bycie Chorwatem i tworzenie (zarówno artystyczne, jak i literackie), nie oznacza automatycznie udziału we współtworzeniu kultury chorwackiej, gdyż wymaga to skupienia swej działalności na narodzie i ojczyźnie, nie zaś funkcjonowaniu w myśl zasady ars gratia artis ${ }^{40}$.

Istotnym przykładem „działalności orędowniczej” V. Nikolicia jest wstęp Kultura $i$ sloboda - uz jubilarni zbornik „Hrvatske revije” z 1976 roku, stanowiący podsumowanie dwudziestopięciolecia pracy inteligencji emigracyjnej na rzecz dziedzictwa kulturowego Chorwatów. To właśnie w nim V. Nikolić rozwiewa wątpliwości, jakoby działalność kulturalna nie przynosiła efektów w walce o wolność - dominantę i wspólny grunt dla wszystkich, którym zależy na przyszłości Chorwacji, co znajduje potwierdzenie w słowach:

[...] nerijetko srećemo pojedince (čak i skupine), koji misle, kako kulturni rad općenito [...] ne pridonosi, bar ne vidljivo i neposredno, borbi hrvatskog naroda za njegovu slobodu. A borba za slobodu je najvažnija: ona je prva - misle oni, a zajedno s njima mislimo tako i mi sami. ${ }^{41}$

Dla emigrantów pisarstwo jest czymś, co przybliża ich do ojczyzny, pomimo znaczącej odległości od Domu - stanowi zatem wypełnianie nostalgii i przejaw wal$\mathrm{ki}$ - zarówno z tęsknotą, jak i w imię idei niepodległości; jest również przygotowaniem do tego, by wolność, po jej uzyskaniu, dobrze wykorzystać. Literatura jako nośnik języka chorwackiego, nie może istnieć bez więzi z narodem. Podobnie jest i z samą Chorwacją, która - zdaniem Nikolicia - bez słowa pisanego ${ }^{42}$ byłaby martwa. Symptomatyczna wydaje się także metaforyka, jaką posługuje się autor w dalszej czę-

niezależność działania w ramach SFRJ. Rozwiązanie to, choć poprawiające sytuację Chorwatów, nie zaspokoiło ich ambicji narodowych; M. J. Zacharias, Chorwacka ,, wiosna" i serbski ,,liberalizm": konflikty polityczne w Jugosławii na poczatku lat siedemdziesiatych, „Dzieje Najnowsze” 2000, t. 32, nr 2, s. 99 120; http://bazhum.muzhp.pl/czasopismo/309/?idno=1643 [dostęp: 17 kwietnia 2018].

${ }^{39}$ Ze względu na dużą liczbę publikacji, które ukazały się na łamach „Chorwackiej Rewii”, autor artykułu przedstawił kilka reprezentatywnych tekstów Vinka Nikolicia. Stanowią one wstępy do jubileuszowych wydań czasopisma.

${ }^{40}$ Hrvatska revija - Jubilarni zbornik 1951-1975, red. Vinko Nikolić, München-Barcelona 1976, s. VI.

${ }^{41}$ Nierzadko spotykamy jednostki (nawet i grupy), które myśla, że działalność kulturalna [...] zasadniczo nie przyczynia się, a przynajmniej nie w widoczny i bezpośredni sposób, do walki chorwackiego narodu o jego wolność. A walka o wolność jest najważniejsza: ona jest pierwsza-myśla Ci [watpiącyprzyp. autor pracy], a z nimi myślimy w ten sposób także i my sami; ibidem, s. V.

42 Ibidem, s. VI. 
ści artykułu - twórczość (w tym wypadku odnosząca się do pozycji Hrvatska revija Jubilarni zbornik...) ma stanowić „Pomnik Chorwackiej Wolności”, który jednocześnie spełnia rolę krypty dla wszystkich męczenników narodu, miejsce pamięci oraz dowód na chorwacką wolę i prawo do wolności ${ }^{43}$.

V. Nikolić zaznacza, że „Chorwacka Rewia” to tworzenie kultury przez emigrantów - szczególnie od chwili, gdy naród został dotknięty przez reperkusje ideologii jugosłowiańskiej trwające od 1945 roku, w wyniku których śmierć poniosło wielu Chorwatów - w tym także artystów. Ze względu na pamięć o ofiarach, twórczość emigracyjna jest tak ważna, gdyż stanowi spłatę długów, jak i obowiązek przejęcia powinności po zmarłych twórcach. Pomimo częstego niezrozumienia motywów, jakimi kierowali się V. Nikolić i jego współpracownicy, chorwacka emigracja przyjęła postawę szerzenia kultury jako protestu, który miał nie tylko wyprowadzić naród ku niepodległości, ale również przygotować Chorwatów do budowy własnej tożsamości w wolnym państwie i nauczenia się wolności, która nie jest przymiotem otrzymanym, lecz wypracowanym $^{44}$. Siła, z jaką działali uczestnicy chorwackiego exodusu po zakończeniu II wojny światowej - zdaniem Nikolicia ${ }^{45}$ - powinna przypominać tę, z jaką bracia Stjepan i Antun Radiciowie (politycy Chorwackiej Partii Chłopskiej) dążyli do uzyskania autonomii przez Chorwację w czasach Królestwa Serbów, Chorwatów i Słoweńców.

V. Nikolić uważał, że choć kultura nie zawsze może uniknąć upolitycznienia, sama polityka powinna ulec ukulturalnieniu, aby nie ograniczała wolności sztuce, gdyż prowadzi to do dysonansu w jej postrzeganiu i sprzyja zagubieniu moralności ${ }^{46}$. Wyrażał on dezaprobatę wobec chorwackich artystów służących reżimowi (co wydaje się nieco ironiczne w odniesieniu do poglądów, jakie przejawiał w młodości!), uciekających tym samym od Prawdy, Dobroci i Piękna ${ }^{47}$ - wartości etycznych, jakim winien służyć twórca. Warto również podkreślić emocje, którym ulega autor, pisząc o tych działaczach opowiadających się po stronie dyktatury ${ }^{48}$ - żyli oni w przekonaniu, że polityka pozwala na wszystko, a osiąganie celu jest dozwolone bez względu na środ-

${ }^{43}$ V. Nikolić odnosi się także do okładki publikacji Jubilarni zbornik..., na której znajduje się ilustracja przedstawiająca latarnię morską, czyli symbol wskazujący drogę, w tym przypadku do Wolności (mentalnej) Chorwatów; ibidem, s. VII.

${ }^{44}$ Ibidem, s. VII-IX.

${ }^{45}$ Analogia zastosowana przez V. Nikolicia wydaje się nietrafna, ze względu na emfazę znaczenia chorwackiego exodusu po II wojnie światowej w odniesieniu do losów chorwackiej niepodległości i porównaniu ich z czynami braci Radić.

${ }^{46}$ Hrvatska revija - Jubilarni zbornik..., s. VIII.

${ }^{47}$ Zachowano oryginalną pisownię dużymi literami, która świadczy o wadze, jaką przypisywał Nikolić wymienionym wartościom; ibidem.

${ }^{48}$ V. Nikolić w ten sposób nawiązuje między innymi do Vladimira Nazora, nazywając go tchórzem z powodu poparcia jugostowianskiej dyktatury w wyborach parlamentarnych w 1935 roku oraz ze względu na dołączenie do oddziałów partyzanckich Josipa Broza Tity, czy Marina Franičevicia, który w 1951 roku, na łamach czasopisma „Republika“" oskarżył chorwacką diasporę o zdradę ojczyzny i ucieczkę z kraju; ibidem, s. 10. 
ki, do których zalicza się: szkalowanie własnego narodu, posługiwanie się w twórczości uproszczonym modelem świata, czy wreszcie brak obiektywizmu. Jest to również tragiczna diagnoza kondycji kultury chorwackiej (zarówno emigracyjnej, jak i rodzimej), gdyż twórczość ponadnarodowa i wynikający z niej merkantylizm, przesłaniają sens działania na korzyść narodowego dziedzictwa.

Partyzanci - pisał V. Nikolić - są ,czerwoni” nie tylko ze względu na reprezentowaną ideologię, ale także chorwacką krew ${ }^{49}$ na swych rękach ${ }^{50}$. Wolą redaktora „Chorwackiej Rewii” było przeciwstawienie się podziałowi Chorwatów i uświadomienie im rzeczywistego braterstwa całego narodu, a także konieczności wzajemnego poszanowania godności drugiego człowieka, gdyż pomimo różnic najważniejsza jest Chorwacja. Takie założenie widoczne było już w pierwszym numerze czasopisma, o którym przypomina Nikolić w jednym ze swych wstępów w „Chorwackiej Rewii”: NE ĆEMO SLUŽITI NIKOME, NEGO SAMO I ISKLJUČIVO HRVATSKOJ I NJEZINOJ BORBI ZA DRŽAVNU SAMOSTALNOST. ${ }^{51}$. Co więcej, Rewia - zdaniem autora - powinna przejąć na siebie część chorwackiej walki narodowej - głównie na polu kulturowym, zrzeszając tym samym wokół siebie wszystkich znaczących autorów emigracyjnych, by wypełnić pustkę, jaka powstała w chorwackiej kulturze w ostatnich stuleciach ${ }^{52}$.

\section{PRÓBA ROZLICZENIA Z PRZESZŁOŚCIĄ?}

Samo założenie jedności stoi w sprzeczności z faktem, iż dla Nikolicia pierwszą wizją tożsamą z wolnością narodu chorwackiego było państwo NDH, któremu służył w latach młodości jako zwolennik Ante Pavelicia. U Nikolicia dostrzegalne jest także znaczące antagonizowanie Jugosławii (jako państwa o ustroju komunistycznym) wobec Chorwatów, co znajduje potwierdzenie w słowach: [...] svaka Jugoslavija, kraljevska ili komunistička, uvijek samo jedna zla maćeha za svakog Hrvata ${ }^{53}$. Z drugiej zaś stro-

\footnotetext{
${ }^{49}$ Należy mieć jednak na uwadze, że reżim komunistyczny w Jugosławii był wrogo nastawiony nie tylko wobec tych, którzy bez względu na narodowość stanowili tzw. opozycję ideologiczną, ale i działaczy komunistycznych, mogących zagrozić pozycji samego J.B. Tity. Wśród nich znajdował się między innymi Andrija Hebrang, sekretarz Związku Komunistów Chorwacji (Savez komunista Hrvatske), który miał uchodzić w oczach Stalina za nowego, potencjalnego przywódcę Jugosławii, zanim doszło do jej wykluczenia z Kominformu; J. A. Irvine, Tito, Hebrang i hrvatsko pitanje, 1943.-1944. w: „Časopis za suvremenu povijest”, Vol. 24, No. 1, Zagreb 1992., s. 21-23.

${ }^{50}$ Hrvatska revija - Jubilarni zbornik..., s. VIII.

${ }^{51}$ NIE BEDDIEMY SEUŻYĆ NIKOMU, JAK TYLKO I WYŁACZNIE CHORWACJI I JEJ WALCE O NARODOWA NIEZALEŻNOŚĆ; Četrdeseta godina „Hrvatske revije” w: „Hrvatska revija. Kulturnoknjiževni tromjesečnik: pokrenut godine 1951”1990, R. 40, nr 1 (München - Barcelona), s. 5.

52 Ibidem.

${ }^{53}$ [...] każda Jugosławia, królewska czy komunistyczna, zawsze [jest] tą samą złą macochą dla każdego Chorwata; Hrvatska revija - Jubilarni zbornik..., op. cit., s. X.
} 
ny, nie sposób nie przytoczyć słów samego autora, jakie opublikował na łamach 40 . numeru ${ }^{54}$ „Chorwackiej Rewii”, jeszcze w latach sześćdziesiątych:

Našim je zajedničkim neprijateljima neobično krivo, što je HR [Hrvatska revija], okupila i bivše Jugoslavene, i bivše (i sadašnje) ustaše, i bivše (i sadašnje) HHS-ovce ${ }^{55}$, zatim pripadnike raznih hrvatskih skupina i društava, te ogromnu većinu nezavišnjaka - sve Hrvate jednog pokraj drugog i tako ostvarila hrvatsko kulturno jedinstvo, a to je upravo njezin veliki i prvi zadatak. [...] Mi nemamo ambicije da budemo ustaško glasilo, ali niti HHS-ovačko, a najmanje jugoslavensko. Naša je jedina velika amibicija da budemo hrvatsko glasilo, što jasno kaže i naše ime, pa je naša HR. ${ }^{56}$

O ile powyższy cytat nie jest całkowitym i jednoznacznym odcięciem się od dawnych poglądów autora, o tyle, kilka stron dalej możemy odnaleźć fragmenty, które podważają słuszność jednoznacznego kojarzenia redaktora „Chorwackiej Rewii“ z ruchem ustaszowskim; V. Nikolić pisał, że nie jest istotne, iż serbscy „bracia“ nazywają Rewię ,proustaszowską“, gdyż dla Serbów wszyscy Chorwacji, którzy opowiadają się za stanowieniem chorwackiego narodu, są ustaszami. ${ }^{57}$ I choć na pierwszy rzut oka, zdanie to wydaje się nacechowane negatywnym nastawieniem do Serbów, V. Nikolić w kolejnych słowach podkreślił fakt, że porażka dotknęła już obu narodów - tak chorwackiego, jak i serbskiego; w ciągu ostatnich dziesięcioleci przelano krew wielu tamtejszych mieszkańców, co doprowadziło do wzajemnej nienawiści i - w konsekwencji - oddalania się siebie Serbów i Chorwatów. Nikolić pisał: Što zato, što će nam nakon ovoga sa srpske strane reći, da smo proustaška?! Kad tražimo pravdu (znači slobodu) za Hrvatsku, ne želimo je graditi na nepravdi ni prema kome, najmanje prema srpskome narodu. ${ }^{58}$. Powyższe zdanie jest ważną deklaracją, ze strony chorwackiego literata i znaczącym opowiedzeniem się przeciw wizji, z jaką utożsamiał się w czasach państwa NDH (jak również wobec zbrodni, jakie dokonali ustasze na Serbach). Dalszy fragment artykułu Četrdeseta godina „Hrvatske revije” to coraz silniejsze polaryzacja osoby Nikolicia i pojęcia faszyzmu - podczas gdy dla Serbów (także tych o poglądach demokratycznych), „Chorwacka Rewia“ miałaby być „proustaszowską“, o tyle „za naše velike Hrvate - izdajice [smo] Hrvatstva; mi smo

${ }^{54}$ Četrdeseta godina ,Hrvatske revije”..., op. cit.

${ }^{55}$ Hrvatska seljačka stranka (pol. Chorwacka Partia Chłopska).

${ }^{56}$ Naszym wspólnym wrogom jest niezwykle źle z powodu skupienia przez „Chorwacka Rewię” [wokół siebie] i bylych Jugostowian, i bylych (i obecnych) ustaszy, i bylych (i obecnych) zwolenników HSS, a zatem członków różnych grup i społeczności, a także ogromnej większości osób neutralnych - wszystkich Chorwatów, jednego obok drugiego - i tak [„Chorwacka Rewia”] urzeczywistniła chorwacka wspólnotę kulturalna, a to jest wtaśnie jej wielkim i pierwszym zadaniem. Nie mamy ambicji, by być organem ustaszowskim, HSS-owskim, a najmniej-jugoslowiańskim. Nasza jedyna wielka ambicja jest być chorwackim organem, co jasno wyraża nasze imię, bo to nasza HR [Chorwacka Rewia]; „Četrdeseta godina „Hrvatske revije”..., op. cit., s. 9.

57 Ibidem, s. 17.

${ }^{58}$ Dlaczego po tym [wszystkim] padna stowa po serbskiej stronie, że jesteśmy proustaszowskim [czasopismem]? Gdy szukamy sprawiedliwości (to jest: wolności) dla Chorwacji, nie chcemy jej budować na niesprawiedliwości przeciwko komukolwiek, a najmniej przeciwko serbskiemu narodowi.; ibidem, s. 17. 
im nekarakteri, jer da smo, navodno, izdali ustaštvo." 59 , zaznaczając dalej, że społeczność „Chorwackiej Rewii” dba o uszanowanie wszystkich opinii i ochronę prawa wolności - dla samych siebie (jako autorów tekstów), jak i całego czasopisma.

Literat wyraźnie zaznaczał też chęć budowania wspólnej Chorwacji - nie tylko dla samych Chorwatów, ale także i Serbów, którzy w niej mieszkali, co podkreślił słowami (wypowiedzianymi w imieniu zbiorowości):

...Mi bismo ovdje samo željeli upozoriti..., da mi nismo protiv Srba i da mi nikoga ne mrzimo. Srbijancima želimo sreću u njihovoj državi. Ali mi s njima ne želimo imati zajedničke države. Bog nas je prije više stoljeća postavio jedne pokraj drugih, i mi s njima želimo dobro susjedstvo. One pravoslavce u Hrvatskoj, koji se priznaju Srbima, smatramo sinovima naše zajedničke majke, domovine Hrvatske, pa buduća hrvatska država treba biti sredstvo ostavarenja općeg dobra, jednako za sve hrvatske državljane, bez razlike vjere i podrijetla, u skladu s našom drevnom predajom etike i prava, koje ne želimo napustiti. ${ }^{60}$

V. Nikolić na łamach badanego artykułu (bazującego w dużej mierze na jego autorskich tekstach z poprzednich numerów „Chorwackiej Rewii““), przedstawił swoje poglądy na nowo, odcinając się od błędów przeszłości, pisząc również, że od wydania pierwszego numeru „Chorwackiej Rewii“, rozpoczął się okres krytycyzmu - tak wobec samych siebie (jako autorów), jak i każdej innej osoby, która na obiektywną krytykę zasłużyła. W dalszej części tekstu V. Nikolić nadal stanowczo sprzeciwiał się nienawiści wobec kogokolwiek - przeciwnie: wyraził on wdzięczność (sic!) serbskim nieprzyjaciołom, gdyż wrogość ta nie jest wynikiem awersji międzyludzkich, ale silnych różnic obu ideologii narodowych, które wzajemnie się wykluczają; autor wspomniał również o „,chorwackich nieprzyjaciołach“, którym w pewien sposób złożył podziękowania za niesprawiedliwe ataki - wszystkie one sprawiły, że „Chorwacka Rewia“ stała się wielkim dziełem, powstałym pomimo nieżyczliwości wielu środowisk ${ }^{61}$.

Najistoniejszym jednak fragmentem badanego artykułu wydaje się jednoznaczna chęć odseparowania się redaktora naczelnego „Chorwackiej Rewii” od osoby Ante Pavelicia, któremu w przeszłości służył i którego sławił (choćby w przytoczonym wcześniej peanie). Od pierwszego numeru czasopisma, wspominano głównie o dwóch nazwiskach - dr Antuna Bonifačicia i Vinka Nikolicia. O ile ten pierwszy

${ }^{59}$ Dla naszych wielkich Chorwatów [postulujących ideę wielkiej Chorwacji w założeniu NDH - S.P.] [jesteśmy] zdrajcami Chorwackości; jesteśmy dla nich bez charakteru [uczciwości], ponieważ, rzekomo, zdradziliśmy myśl ustaszowska, ibidem.

60 ... Chcielibyśmy $w$ tym miejscu zaznaczyć..., że nie jesteśmy przeciw Serbom i nikogo nie nienawidzimy. Życzymy im szczęścia w ich kraju. Ale nie chcemy mieć z nimi wspólnego państwa. Bóg, przed wieloma stuleciami, postawił nas jednych obok drugich, a my pragniemy z nimi dobrego sasiedztwa. [Osoby] prawosławne w Chorwacji, które identyfikuja się jako Serbowie, postrzegamy jako synów naszej wspólnej matki, ojczyzny Chorwacji, gdyż przyszłe chorwackie państwo powinno być środkiem urzeczywistnienia dobra ogólnego, równego dla wszystkich obywateli, bez względu na wiarę i pochodzenie, stosownie do naszego starożytnego zobowiązania etyki i prawa, z którego nie zamierzamy zrezygnować., ibidem, s. 9-10.

61 Ibidem, s. 18. 
pozostał przez długi czas postrzegany jako mniej związany z poglądami naczelnika NDH (co nie było prawdą), o tyle Nikoliciowi (jak i chorwackiej opinii publicznej) fakt ciągłego łączenia go z Paveliciem coraz mocniej przeszkadzal ${ }^{62}$. Współpraca twórców „Chorwackiej Rewii“ zakończyła się w momencie wyjazdu Bonifačicia do Chicago, co V. Nikolić zaliczył do pozytywów, gdyż, jak pisał: Bolje je tako, jer inače bi kasnije između nas bilo došlo do ideološko-političkog razilaženja, jer tada je dr. Bonifačić prešao na suradnju s drom Pavelićem. Velika šteta: hrvatskoj politici nije koristio, a hrvatsku je književnost odštetio, prikratio. ${ }^{63}$. Potwierdzeniem słów samego Nikolicia, wydaje się opinia Branimira Donata w tekście poświęconym ideologii ustaszowskiej w literaturze ${ }^{64}$ : Životni i književni put Vinka Nikolića bio je različit. Međutim, [Bonifačić je] [...] u izbjeglištvu ostao jednim od malobrojnih privrženika ne samo Pavelićeve propale politike nego i njega, iako diskreditiranog političara u egzilu $[\ldots]^{65}$.

Wydaje się zatem, że wraz z wyjazdem Bonifačicia, Nikolić rozpoczął nowy kierunek w swej walce o niepodległą Chorwację; wybrał drogę, która nie łączyła go już z Ante Paveliciem, a z pewnością był przeciw takiemu postrzeganiu jego osoby.

\section{RAJ ODZYSKANY}

Aby w pełni zrozumieć, jak ważna dla Nikolicia była ojczyzna i jej niezależność, warto zwrócić uwagę na wstęp napisany przez niego do książki Vinka Grubišicia Hrvatska književnost u egzilu ${ }^{66}$, w którym przedstawił swoje emocje związane z powrotem do Chorwacji po kilkudziesięciu latach wygnania. U DANU velikog Povratka ... donijet ćemo naše književne mrvice, a s njima i naša srca, izmučena patnjama i čežnjama,

${ }^{62}$ Meni je smetala (i kod hrvatske javnosti) moja dotadašnja suradnja s dr Pavelićem, dok je dr. Bonifačić onda još bio javno neopredijeljen. (Tłum.: Mnie - i chorwackiemu społeczeństwu - przeszkadzała dotychczasowa wspótpraca z dr Paveliciem, podczas gdy dr Bonifačić byt jeszcze publicznie niezaangażowany.), ibidem, s. 18-19.

${ }^{63}$ Takjest lepiej, gdyż w przeciwnym razie doszłoby później między nami do ideologiczno-politycznego poróżnienia, ponieważ wtedy dr Bonifačić przeszedl na wspótpracę z dr Pavelićem. Wielka szkoda: nie przyczynit się chorwackiej polityce, podczas gdy chorwackiej literaturze zaszkodzil, ukrócit [ją]; ibidem.

${ }^{64}$ B. Donat, Ideje ustaškog pokreta i njihovo tumačenje u djelima ideologa i književnika w: Radovi Leksikogravskog zavoda Miroslav Krleža - Razdio za društvene i humanističke znanosti, red. D. Brozović, Zagreb 1995; http://www.enciklopedija.hr/natuknica.aspxhttp://www.lzmk.hr/33-projekti/radovi-leksikografskoga-zavoda-miroslav-krleza/259-radovi-leksikografskoga-zavoda-miroslav-krleza-4?ID=26416 [dostęp: 17 kwietnia 2018].

${ }^{65}$ Życiowa i literacka droga Vinka Nikolicia była inna. Jednakże [Bonifačić] [...] na uchodźstwie pozostat jednym z niewielu lojalnych wobec nie tylko nieudanej polityki Pavelicia, ale i niego - choć już zdyskredytowanego polityka na wygnaniu; ibidem, s. 199.

${ }^{66}$ V. Nikolić, Predgovor w: V. Grubišić, Hrvatska književnost u egzilu, Knjižnica Hrvatske revije, Barcelona-München 1991. 
da zajedno svjedoče koliko smo pod tuđim nebom živjeli s našom Hrvatskom [...]. ${ }^{67}$ w ten oto sposób, odwołując się do własnych słów z 1957 roku, autor rozpoczął tekst, w którym podkreślona została realizacja marzeń o chorwackiej niepodległości. Pomimo ogromnej radości, V. Nikolić ubolewa, że innym jego rodakom, rozsianym po całym świecie ze względu na rządy w czasach socjalistycznej Jugosławii, nie starczyło życia, aby doczekać powrotu do swego kraju. Odczuwalny dla niego był również dystans dzielący repatriantów od pozostałych Chorwatów, którzy w większości, ze względu na ówczesną władzę, nie mieli możliwości poznania twórczości emigracyjnej, pomimo że emigranci starali się śledzić sytuację rodaków na bieżąco, o czym świadczą słowa:

[...] mi se međusobno ne poznajemo. Mi više poznajemo njih, negoli oni nas. Mi smo, koliko se to moglo, pratili i suosjećali život Hrvatske, i zemlje i ljudi, ali oni nisu mogli [nisu smjeli] pratiti život nas u emigraciji, koja je bila proglašena i zločinačkom i opasnom, pa je i najbezazleniji dodir s njom [čak i obiteljski] bio kažnjiv i kažnjen. ${ }^{68}$

Powyższy cytat wydaje się znaczącym dowodem na silne działanie cenzury i systemu politycznego funkcjonującego w Jugosławii - szczególnie biorąc pod uwagę karalność zainteresowania bądź chęci kontaktu z artystami politycznej chorwackiej diaspory.

Dodatkowym dowodem niedostatecznej świadomości znaczenia „Chorwackiej Rewii” dla Chorwatów i ich kultury są słowa Karla Mirtha zawarte w pierwszym po śmierci Nikolicia numerze czasopisma ${ }^{69}$, gdzie pisze:

O iznimno istaknutu mjestu koje zauzimaju Nikolić i njegova Hrvatska revija u povijesti hrvatske kulture pisalo se i pisat će se. Revija je riznica dragocjenih podataka i putokaz za mnoge slabo poznate i nepoznate putove kulturalnog i političkog djelovanja generacije iskorijenjene iz Hrvatske, koja je djelovala u mnogo pravaca, mnogo zemalja i raznih sredina. O tom radu se u Hrvatskoj i danas najmanje zna. ${ }^{70}$

Mając na uwadze powyższe słowa, można stwierdzić, że chorwacka kultura rozwijała się dwutorowo i niezależnie od siebie; brak znajomości działalności kultural-

${ }^{67}$ W DNIU wielkiego Powrotu... przyniesiemy nasze literackie okruchy, a z nimi i nasze serca, umęczone cierpieniami i tęsknotami, by razem świadczyly jak pod obcym niebem żyliśmy z nasza Chorwacja [...]; ibidem, s. 5.

68 [...] nie znamy się wzajemnie. My bardziej znamy ich, aniżeli oni nas. My, na ile to było możliwe, śledziliśmy i odczuwaliśmy życie Chorwacji ( $\mathrm{kraju}$, i ludzi), ale oni nie mogli (nie śmieli) śledzić naszego życia na emigracji, która została określona jako kryminalna i niebezpieczna, więc choćby najniewinniejszy kontakt z nia [nawet rodzinny] byt karalny $i$ karany; ibidem.

${ }^{69} \mathrm{~K}$. Mirth, S Nikolićeva puta povratka domovini s Hrvatskom revijom, „Hrvatska revija” 1997, nr 47, s. 435-445.

${ }^{70} \mathrm{O}$ niezwykle istotnym miejscu, które zajmuje V. Nikolić i jego „Chorwacka Rewia” w historii chorwackiej kultury, pisało się i pisać będzie. Rewia jest skarbcem drogocennych informacji i drogowskazów po wielu nieznanych i słabo poznanych ścieżkach kulturalnej i politycznej działalności pokolenia wykorzenionego z Chorwacji, funkcjonującego wielokierunkowo, w wielu krajach i różnych środowiskach. W Chorwacji - o tej działalności - po dziś wie się niewiele; ibidem, s. 444. 
nej politycznych emigrantów nie dawał szansy poznania innej, zewnętrznej perspektywy postrzegania ojczyzny przez chorwacką diasporę, a tym samym skorzystania z wartości, jakie przekazywała ona swoim rodakom na łamach „Chorwackiej Rewii”. Pomimo tego, V. Nikolić z radością i dumą oddał w ręce swojego narodu cztery dziesięciolecia emigracyjnego dorobku literackiego, jaki powstawał w czasie, gdy wolna Chorwacja była jedynie ideą i niespełnionym pragnieniem. $Z$ tego też względu, pozostawił on ocenę dzieł emigracyjnych narodowi i przyszłym pokoleniom Chorwatów, gdyż tęsknota, jaka kierowała artystami żyjącymi poza swoim krajem, bywała często silniejszym motywem, niż te, na których oparto utwory powstające w ojczyźnie; V. Nikolić sądził, że jeśli samym tekstom miałoby brakować poezji, na pewno nie brakowało ambicji i chęci włożonych w powstanie nowego kanonu chorwackiej literatury. Ta twórczość to również świadectwo licznych pisarzy i ich historii, będących dla przyszłych pokoleń przekazem o tym, jak wyglądały czasy, których nie znają; to także hołd dla wszystkich wydarzeń z okresu powojennego, jakie nie powinny i nie zostały przemilczane dzięki ich działalności. Zdaniem Nikolicia - twórczość emigracyjna to nie tylko historia emigrantów, ale - choćby częściowo - również historia współczesnej Chorwacji i treści, o których w Jugosławii należało milczeć ze względów politycznych ${ }^{71}$.

\section{TRAGEDIA JEDNOSTKI}

Vinko Nikolić to postać o historii równie kontrowersyjnej (ze względu na związki $\mathrm{z}$ faszystowskim państwem $\mathrm{NDH}^{72}$ ), co tragicznej. Jego działania poświęcane ruchowi narodowowyzwoleńczemu opierały się w głównej mierze na uświadamianiu społeczeństwu potrzeby budowania wolności Chorwacji na gruncie szeroko pojętej kultury, gdyż - jak uważał - ojczyzna może istnieć tak długo, jak długo istnieje jej kultura i język. Nie bez znaczenia pozostaje wiara, z jaką pisarz dążył do wyznaczonego celu - przez prawie 50 lat swojego życia walczył on o chorwacką niepodległość, a tym samym wyrwanie się z rąk jugosłowiańskiej dyktatury, którą krytykował wielokrotnie w swoich tekstach. Wysiłki Nikolicia, choć przez długie dekady nie przynosiły pożądanych skutków i zauważalne były niemal jedynie poza granicami Chorwacji, zostały docenione po latach (choć nie od razu) - w czasie, gdy niezależność państwa leżała wyłącznie w rękach jego rodaków.

Jak pisał Dubravko Jelčić w przedmowie do antologii poświęconej Nikoliciowi (Vladimir Kovačić, Vinko Nikolić - Izabrana djela...), wygnanie w starożytnej Grecji było wyrokiem równie ciężkim, co kara śmierci ${ }^{73}$. Ironią losu jest jednak fakt,

\footnotetext{
${ }^{71}$ V. Nikolić, Predgovor w: V. Grubišić, Hrvatska književnost u egzilu..., op. cit., s. 6-9.

${ }^{72}$ Pomimo długoletniego wspierania ustaszowskiej idei, poeta zdaje się odcinać od faszystowskich poglądów, które stanowiły dla niego inspirację w latach młodości.

${ }^{73}$ Vladimir Kovačić, Vinko Nikolić - Izabrana djela..., op. cit., s. 223.
} 
że o ile ostracyzm przewidywał ekspatriację czasową (dziesięcioletnią) dla osób potencjalnie zagrażających demokracji, o tyle Vinko Nikolić spędził poza granicami ojczyzny niemal pół wieku, gdzie o głos ludu i niepodległość walczył za pomocą pióra. Wkład długoletniego redaktora naczelnego „Chorwackiej Rewii” w budowę osnowy dla przyszłości chorwackiej demokracji zdaje się dla jego rodaków być działaniem równie istotnym, co zasługi Klejstenesa obalającego tyranię w Atenach, a dla niego samego - swoistym katharsis. I choć powrót Nikolicia z emigracji był możliwy dopiero pod koniec jego życia (w wieku 78 lat), udało mu się na własnej skórze odczuć, czym jest eleftheria ${ }^{74}$ - pojęcie, bez którego demokracja wyniesiona $\mathrm{z}$ antycznej Grecji nie miała prawa istnieć.

\section{BIBLIOGRAFIA}

Donat B., Ideje ustaškog pokreta $i$ njihovo tumačenje u djelima ideologa i književnika w: Radovi Leksikogravskog zavoda Miroslav Krleža - Razdio za društvene $i$ humanističke znanosti, red. D. Brozović, Zagreb 1995; http://www.enciklopedija.hr/natuknica.aspxhttp://www.lzmk.hr/33-pro jekti/radovi-leksikografskoga-zavoda-miroslav-krleza/259-radovi-leksikografskoga-zavoda-miro slav-krleza-4?ID=26416 [dostęp: 17 kwietnia 2018].

Goldstein I., Goldstein S., Jasenovac i Bleiburg nisu isto, Zagreb 2011, s. 313-317.

Heges C., Fascists Reborn as Croatia's Founding Fathers, "New York Times", $12^{\text {th }}$ of April 1997; https:// www.nytimes.com/1997/04/12/world/fascists-reborn-as-croatia-s-founding-fathers.html [dostęp: 18 kwietnia 2018].

Hrvatska enciklopedija; http://www.enciklopedija.hr/natuknica.aspx?ID=26416 [dostęp: 17 kwietnia 2018].

Hrvatska revija - Jubilarni zbornik 1951-1975, red. V. Nikolić, München-Barcelona 1976.

Irvine J.A., Tito, Hebrang i hrvatsko pitanje, 1943.-1944. w: “Časopis za suvremenu povijest”, Vol. 24, No. 1, Zagreb 1992.

Grubišić V., Hrvatska književnost u egzilu, Knjižnica Hrvatske revije, Barcelona-München 1991.

„Hrvatska revija (kulturno - književni tromjesečnik: pokrenut godine 1951)” 1990, R. 40, nr 1 (MünchenBarcelona).

Jadranić B., Stajališta Hrvatske političke emigracije o hrvatskom proljeću iznesena u najznačajnijem emigrentskom časopisu Hrvatskoj reviji, „Časopis za suvremenu povijest” 2003, t. 35, nr 2; https://hrcak. srce.hr/index.php?show=clanak\&id_clanak_jezik=150301 [dostęp: 17 kwietnia 2018].

Jakir A., Vulić P., Recepcija Bleiburga u hrvatskoj javnosti kao tema povijesnog istraživanja, ,Zbornik radova Filozofskog fakulteta u Splitu" 2016, nr 6-7; https://hrcak.srce.hr/index.php?show=clanak\&id clanak_jezik=227856 [dostęp: 20 kwietnia 2018].

Jelčić D., Predgovor w: Vladimir Kovačić, Vinko Nikolić - Izabrana djela, Stoljeća hrvatske književnosti, red. V. Pavletić, przyg. D. Jelčić, Zagreb 1997, t. 21.

Jelić-Butić F., Ustaše i Nezavisna Država Hrvatska 1941-1945, Zagreb 1977.

Kovačić V., Nikolić V., Izabrana djela. Stoljeća hrvatske književnosti, red. V. Pavletić, przyg. D. Jelčić, Zagreb 1997, t. 21.

Mirth K., S Nikolićeva puta povratka domovini s hrvatskom revijom, "Hrvatska revija" 1997, nr 47, s. $435-445$.

Nikolić V., Molitva za moju Hrvatsku, Buenos Aires 1949.

\footnotetext{
${ }^{74}$ Grec. eleftheria $(\varepsilon \lambda \varepsilon v \theta \varepsilon \rho \imath \alpha)$ - pol. ,wolność”.
} 
Nikolić V., Predgovor, w: V. Grubišić, Hrvatska književnost u egzilu, Barcelona-München 1991.

Nikolić V., Predgovor w: Hrvatska revija - Jubilarni zbornik 1951-1975, red. V. Nikolić, MünchenBarcelona 1976.

Tko je tko u NDH - Hrvatska 1941-1945, red. Z. Dizdar, M. Grčić, S. Ravlić, D. Stuparić, Zagreb 1997. Yeomans R., Army Educators and the Making of a "Total Man" in Late Fascist Croatia, Rory Yeomans w: The "New Man" in Radical Right Ideology and Practice, 1919-45, M. Feldman, J. Dagnino, P. Stocker, London 2018.

Yeomans R., Cults of Death and Fantasies of Annihilation: the Croatian Ustasha Movement in Power, 1941-1945 w: "Central Europe" 2005, t. 3, nr 2; https://www.academia.edu/8131714/Cults_of Death_and_Fantasies_of_Annihilation_The_Croatian_Ustasha_Movement_in_Power_1941_45 [dostęp: 17 lutego 2019].

Zacharias M.J., Chorwacka „wiosna” i serbski „,liberalizm”: konflikty polityczne w Jugosławii na początku lat siedemdziesiatych, „Dzieje Najnowsze” 2000, t. 32, nr 2; http://bazhum.muzhp.pl/ czasopismo/309/?idno=1643 [dostęp: 17 kwietnia 2018]. 
